\title{
Role of vascular endothelial growth factor in protein loss of Ménétrier's disease
}

\author{
TEIKO TAKEDA, KEIICHI MITSUYAMA, OSAMU TSURUTA, \\ SHINICHI KUBOYAMA, SHIGEHIKO KITAZAKI and MICHIO SATA \\ Division of Gastroenterology, Department of Medicine, \\ Kurume University School of Medicine, Asahi-machi 67, Kurume 830-0011, Japan
}

Received April 10, 2006; Accepted June 13, 2006

\begin{abstract}
Vascular endothelial growth factor (VEGF) promotes protein leakage from blood vessels and endothelial cell growth. The expression of transforming growth factor (TGF)- $\alpha$ and its receptor is increased in the gastric mucosa of patients with Ménétrier's disease. Since TGF- $\alpha$ stimulates the expression of VEGF mRNA in cultured keratinocytes, we hypothesized that VEGF may play an important role in the protein leakage of Ménétrier's disease. Immunohistochemistry was performed using specific antibodies against VEGF and CD31 in gastric tissue specimens from 7 patients with Ménétrier's disease and 10 controls. The effect of recombinant TGF- $\alpha$ on VEGF production by cultured lamina propria mononuclear cells (LPMCs) was assessed. VEGF expression was detected for LPMCs and occasional epithelial cells of the gastric mucosa of Ménétrier's patients. VEGF-positive LPMCs were increased in tissues from patients with Ménétrier's disease $(\mathrm{P}<0.001)$. Of the LPMCs, T-lymphocytes and macrophages were the major sources of VEGF. CD31-positive blood vessels were increased in Ménétrier's tissue. $(\mathrm{P}<0.05)$. Recombinant TGF- $\alpha$ induced the production of VEGF in cultured LPMCs $(\mathrm{P}<0.05)$. In conclusion, the increased expression of VEGF, as a result of overproduction of TGF- $\alpha$, may play a key role in the pathophysiology of Ménétrier's disease.
\end{abstract}

\section{Introduction}

Ménétrier's disease is an uncommon disorder of unknown etiology characterized by enlarged gastric folds with foveolar hyperplasia and cystic dilatation of gastric glands (1). Transgenic mice which overexpress transforming growth factor (TGF)- $\alpha$ develop hypertrophic gastropathy similar to

Correspondence to: Dr Keiichi Mitsuyama, Division of Gastroenterology, Department of Medicine, Kurume University School of Medicine, Asahi-machi 67, Kurume 830-0011, Japan

E-mail: ibd@med.kurume-u.ac.jp

Key words: Ménétrier's disease, protein losing gastropathy, vascular endothelial growth factor, transforming growth factor- $\alpha$ that seen in patients with Ménétrier's disease $(2,3)$. The expression of both TGF- $\alpha$ and its receptor is increased in the gastric mucosa of patients with Ménétrier's disease (3). These findings in Ménétrier's patients and in the animal model indicate that TGF- $\alpha$ may be involved in the pathogenesis of Ménétrier's disease. Hypoproteinemia caused by gastric protein leakage is a critical problem in patients with Ménétrier's disease. However, the exact mechanism of protein leakage remains unknown though enhanced microvascular permeability (4), dilated lymphatics (5), and widened epithelial tight junctions (6) in the stomach of patients with Ménétrier's disease have been noted. It has been recently reported that the blockade of the epidermal growth factor receptor is an effective therapy in Ménétrier's patients with severe almunin loss (7).

Vascular permeability factor (VPF) was originally identified as a 34- to 42-kDa glycoprotein secreted by tumor cells (8) This molecule can induce a 50,000-fold greater vascular permeability-enhancing activity than histamine (9). VPF is also a selective endothelial cell growth factor (10), hence its additional name, vascular endothelial growth factor (VEGF) $(11,12)$. Several factors have been shown to induce VPF/VEGF production in vitro $(13,14)$. Of particular interest is a report by Detmar et al demonstrating marked induction of VEGF mRNA by TGF- $\alpha$ in cultured epidermal keratinocytes (15). These findings led us to speculate that VEGF may play a key role in the protein leakage from the stomach of patients with Ménétrier's disease, and, if so, inhibition of VEGF action could be used to treat the hypoproteinemia seen in Ménétrier's patients.

In the present study, we examine for the first time the role of VEGF in the pathophysiology of Ménétrier's disease. These results provide insights into the mechanisms of gastric protein leakage seen in this disorder, and provide a useful framework for developing strategies for therapeutic intervention.

\section{Materials and methods}

Patients and sample collection. Seven patients with Ménétrier's disease were included in this study. The diagnosis was based on characteristic endoscopic and radiological features of Ménétrier's disease. All patients fulfilled the histological criteria for either massive foveolar hyperplasia or hypertrophic lymphocytic gastritis forms of Ménétrier's disease $(6,16-18)$. Table I summarizes the clinical characteristics and 
Table I. Clinical characteristics of patients with Ménétrier's disease.

\begin{tabular}{|c|c|c|c|c|c|c|c|c|c|}
\hline Age/sex & $\begin{array}{l}\text { Gastric } \\
\text { fundus }\end{array}$ & $\begin{array}{l}\text { Involvement } \\
\text { in antrum }\end{array}$ & $\begin{array}{c}\text { Basal pH } \\
(\mathrm{pg} / \mathrm{ml})^{\mathrm{a}}\end{array}$ & $\begin{array}{l}\text { Serum } \\
\text { gastrin } \\
(\mathrm{g} / \mathrm{dl})^{\mathrm{b}}\end{array}$ & $\begin{array}{c}\text { Serum } \\
\text { albumin }\end{array}$ & $\begin{array}{c}\text { Gastric Cl } \\
\alpha 1-\mathrm{AT}^{\mathrm{c}}\end{array}$ & ${ }^{99 \mathrm{~m}} \mathrm{Tc}-\mathrm{HAS}{ }^{\mathrm{d}}$ & $\begin{array}{c}{ }^{131} \mathrm{I}-\mathrm{PVP} \\
(\%)^{\mathrm{e}}\end{array}$ & Histology \\
\hline $68 / \mathrm{M}$ & + & - & 2.4 & ND & 2.5 & 5.4 & ND & ND & $\begin{array}{l}\text { Lymphocytic } \\
\text { gastritis }\end{array}$ \\
\hline $71 / \mathrm{M}$ & + & + & 7.6 & ND & 3.0 & 10.9 & ND & ND & $\begin{array}{l}\text { Massive foveolar } \\
\text { hyperplasia }\end{array}$ \\
\hline $58 / \mathrm{F}$ & + & + & 6.0 & 230 & 1.6 & 31.5 & positive & 7.9 & $\begin{array}{l}\text { Massive foveolar } \\
\text { hyperplasia }\end{array}$ \\
\hline $28 / \mathrm{F}$ & + & + & 8.5 & 203 & 2.2 & ND & positive & ND & $\begin{array}{l}\text { Massive foveolar } \\
\text { hyperplasia }\end{array}$ \\
\hline 79/M & + & - & ND & 450 & 3.3 & ND & positive & 5.5 & $\begin{array}{l}\text { Massive foveolar } \\
\text { hyperplasia }\end{array}$ \\
\hline $74 / \mathrm{M}$ & + & - & ND & 140 & 2.8 & ND & positive & ND & $\begin{array}{l}\text { Massive foveolar } \\
\text { hyperplasis }\end{array}$ \\
\hline
\end{tabular}

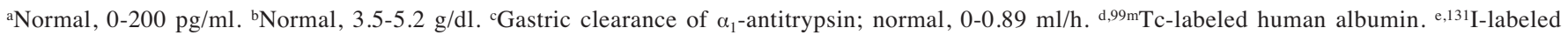
polyvinylpyrrolidone; normal, $0-1.5 \%$. ND, not done.

laboratory data of each patient. Protein leakage in the stomach was examined in the seven patients using the following established methods: gastric clearance of $\alpha_{1}$-antitrypsin (19), three patients; ${ }^{131} \mathrm{I}$-labeled polyvinylpyrolidone excretion over 4 days, two patients; and abdominal scintigraphy using 99mTc-labeled human serum albumin (20), four patients.

Mucosal biopsy specimens were obtained from the gastric body during gastroscopy. They were fixed in 10\% formalin and embedded in paraffin. Control mucosal specimens were obtained from grossly and microscopically normal mucosa of patients who had undergone gastroscopy and biopsy for investigation of gastrointestinal symptoms, but where no abnormality was found.

This study was performed according to the Helsinki Declaration and was approved by the Medical Ethics Committee of Kurume University Hospital. Informed consent was obtained from each patient who agreed to participate in this study.

Immunohistochemistry. Immunohistochemical study was performed on $6-\mu \mathrm{m}$ paraffin sections of gastric mucosa which were deparaffinized in xylene and rehydrated in graded ethanol solution. Endogenous peroxidase activity was blocked with $0.03 \%$ hydrogen peroxide and sodium azide (Dako, CA, USA) for $10 \mathrm{~min}$, and washed with phosphatebuffered saline (PBS). The tissue sections were pretreated with serum-free protein blocking (Dako, CA) for $10 \mathrm{~min}$, incubated overnight at $4{ }^{\circ} \mathrm{C}$ with primary antibody, and washed with PBS. Monoclonal antibodies against human VEGF (2E1, $10 \mu \mathrm{g} / \mathrm{ml}$; IBL, Gunma, Japan), T cell markers CD45RO (UCHL1, 1:100; Dako, Glostrup, Denmark) $(21,22)$, macrophage markers CD68 (PG-M1, 1:100; Dako, Glostrup), B cell markers CD20 (L26, 1:100; Dako, Glostrup) and endothelial cell markers CD31 (JC/70A, 1:20; Dako, Glostrup) (23-25) were used as primary antibodies. The slides were then incubated with anti-mouse biotinylated immunoglobulins (Vectastain ABC Kit, CA) for 30 min, washed with PBS, incubated with avidin-biotinylated horseradish peroxidase complex for $30 \mathrm{~min}$, and washed with PBS. The slides were then stained with diaminobenzidine tetrahydrochloride substrate at room temperature, rinsed in tap water for $2 \mathrm{~min}$, counterstained with Harris' hematoxylin, and dipped in saturated lithium carbonate solution for blueing. For morphometric analysis, each microscope slide was analyzed independently in a blind manner by two trained pathologists. After counting the number of VEGF-positive cells or CD31positive blood vessels in random areas on each section, the mean cell density was calculated using a semiautomatic computerized imaging analyzer (Nikon, Tokyo, Japan).

Isolation of lamina propria mononuclear cells and culture. LPMCs of the stomach were isolated with slight modifications $(26,27)$. Specimens were obtained from patients with gastric cancer during gastrectomy. The specimens were collected from the operating room within 5 min of removal. Each specimen was opened longitudinally along the greater curvature and rinsed with cold $0.9 \%$ saline. The non-cancerous mucosa of the gastric body was freed from the underlying submucosal connective tissue, and was removed in strips. The gastric mucosal specimens were placed in Hanks' balanced salt solution without calcium and magnesium (CMFHBSS) with 5\% fetal calf serum (FCS) (Gibco, Grand Island, NY, USA) containing $1 \mathrm{mM}$ ethylenediamine tetraacetic acid (Analar BDH Chemicals, Poole, UK) in a V-bottom container. The specimens were then agitated for $1 \mathrm{~h}$ at $37^{\circ} \mathrm{C}$ to remove the epithelial layer; the remaining specimens were washed with RPMI 1640. The specimens were treated with collagenase type I (120 U/ml; Sigma Chemical, St. Louis, MO) for $3 \mathrm{~h}$ at $37^{\circ} \mathrm{C}$ with agitation. The cellular supernatant was then washed three times, and the number and viability of isolated LPMCs 


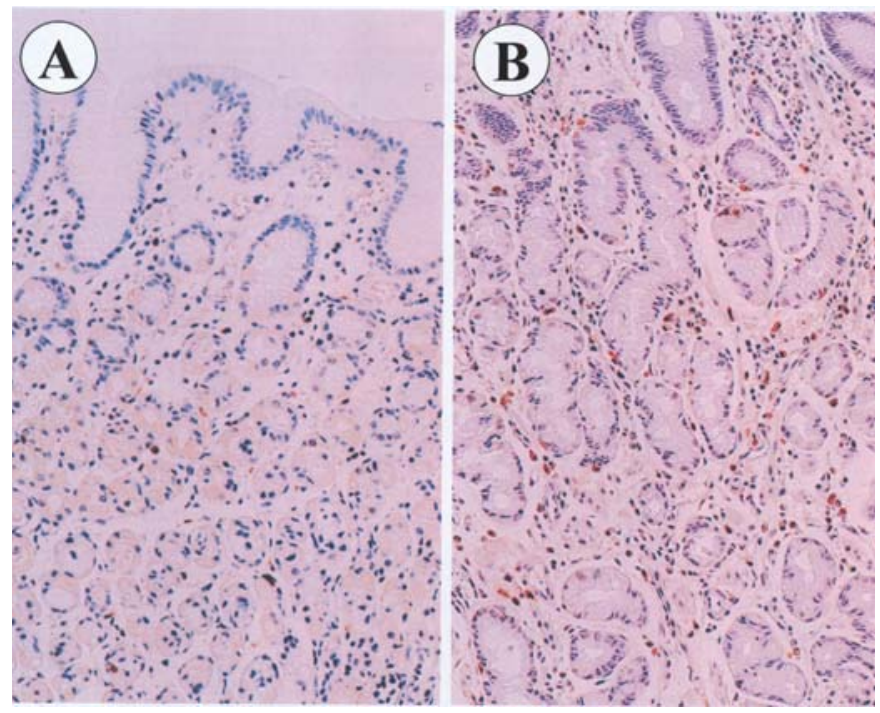

Figure 1. Immunohistochemical localization of VEGF in the gastric mucosa of a control subject (A) and a patient with Ménétrier's disease (B). Patients who underwent gastroscopy, but where no abnormality was found, served as control subjects. Control slides incubated with mouse control IgG or without primary antibody showed no immunoreactivity. The degree of staining was greatly reduced after preincubating the primary antibody with human recombinant VEGF.

were determined using acridine orange and ethidium bromide. The percentage of viable cells in each specimen was consistently $>85 \%$. The cells $\left(2 \times 10^{6} / \mathrm{ml}\right)$ were cultured with various concentrations of recombinant $\mathrm{TGF}-\alpha$ (Genzyme, Cambridge, MA, USA) for $24 \mathrm{~h}$ at $37^{\circ} \mathrm{C}$ in an atmosphere of $5 \% \mathrm{CO}_{2}$. The culture supernatant was collected, filtered through a $0.45-\mu \mathrm{m}$ filter, and stored frozen until assayed for VEGF by enzyme-linked immunosorbent assay (ELISA) $(28,29)$.

ELISA for VEGF. The level of VEGF in the culture supernatants was measured by a colorimetic ELISA with slight modifications $(28,29)$. This assay employed an antihuman VEGF polyclonal antibody elicited in rabbits by immunizing recombinant $\mathrm{VEGF}_{121}$ protein (Toagosei Chemical Industry, Tsukuba, Japan), which was prepared with glutathione-S-transferase gene fusion system (Pharmacia Biotech., Tokyo, Japan). Ninety-six-well microtiter plates (Combiplate EB, Labsystems, Helsinki, Finland) were coated with $5 \mu \mathrm{g} / \mathrm{ml}$ of the purified anti-VEGF antibody in $0.1 \mathrm{M}$ $\mathrm{NaCl}$ and $0.25 \mathrm{M}$ carbonate buffer ( $\mathrm{pH} 9.5), 0.1 \mathrm{M} \mathrm{NaCl}$, and $0.1 \% \mathrm{NaH}_{3}$. The samples $(100 \mu \mathrm{l})$ and serially diluted VEGF were added to the wells and incubated for $1 \mathrm{~h}$ at $22^{\circ} \mathrm{C}$. After washing the wells, $100 \mu 1$ of horseradish peroxidaseconjugated $\mathrm{Fab}$ of the anti-VEGF antibody was added and incubated for $1 \mathrm{~h}$ at $22^{\circ} \mathrm{C}$. The wells were washed, and then incubated with the enzyme substrate (o-phenylenediamine, Sigma Chemical) at $22^{\circ} \mathrm{C}$ for $30 \mathrm{~min}$. The absorbance of each sample was measured with a plate reader, and the VEGF content of each sample was estimated from the standard curve of $\mathrm{VEGF}_{121}$. This ELISA reacts with all isoforms of VEGF.

Statistical analysis. Each value is expressed as the mean \pm SEM unless otherwise stated. Statistical analysis was performed with Student's t-test, Mann-Whitney U test and
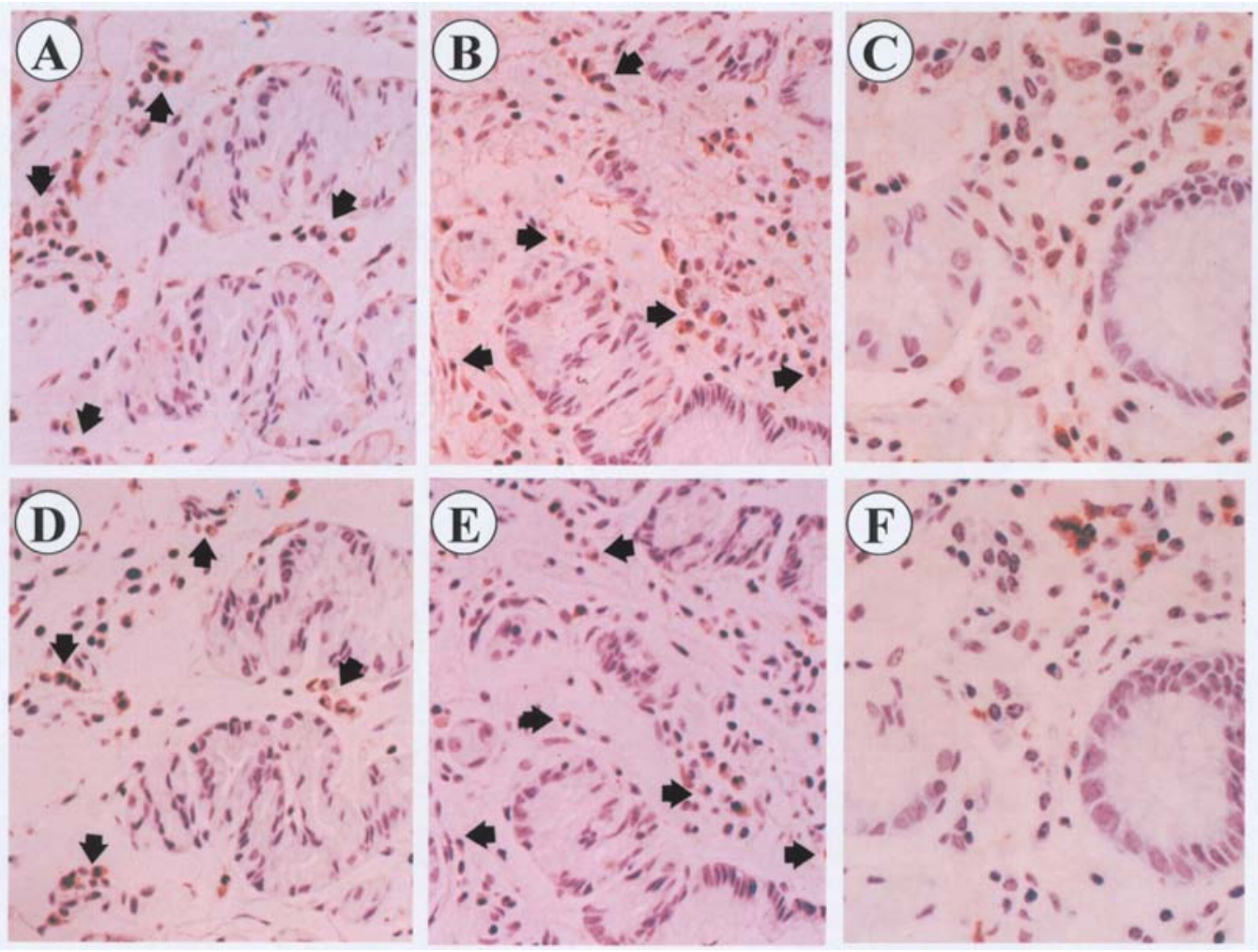

Figure 2. High-power view of serial sections of gastric mucosa from a patient with Ménétrier's disease. The tissue is stained with anti-human VEGF antibody (A) or CD45RO (D). VEGF was localized in T-lymphocytes (see arrows). Staining is seen with anti-human VEGF antibody (B) and CD68 (E). VEGF was localized in macrophages (see arrows). Cells are stained with both anti-human VEGF antibody (C) and CD20 (F). VEGF was not seen in B-lymphocytes. 
A

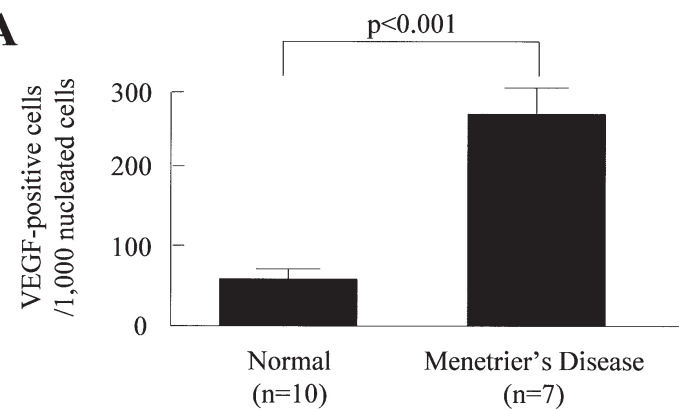

B

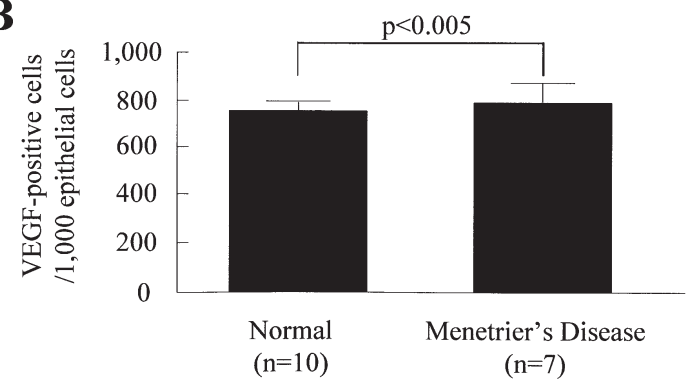

Figure 3. The number of VEGF-positive cells in the gastric mucosa of patients with Ménétrier's disease $(n=10)$ and controls $(n=7)$. (A) The number of VEGF-positive mononuclear cells in the gastric lamina propria. Results are expressed as the number of VEGF-positive mononuclear cells per 1,000 mononuclear cells in the lamina propria. (B) The number of VEGF-positive epithelial cells in the gastric mucosa. Results are expressed as the number of VEGF-positive epithelial cells per 1,000 epithelial cells in the gastric mucosa. The mean \pm SEM is shown.

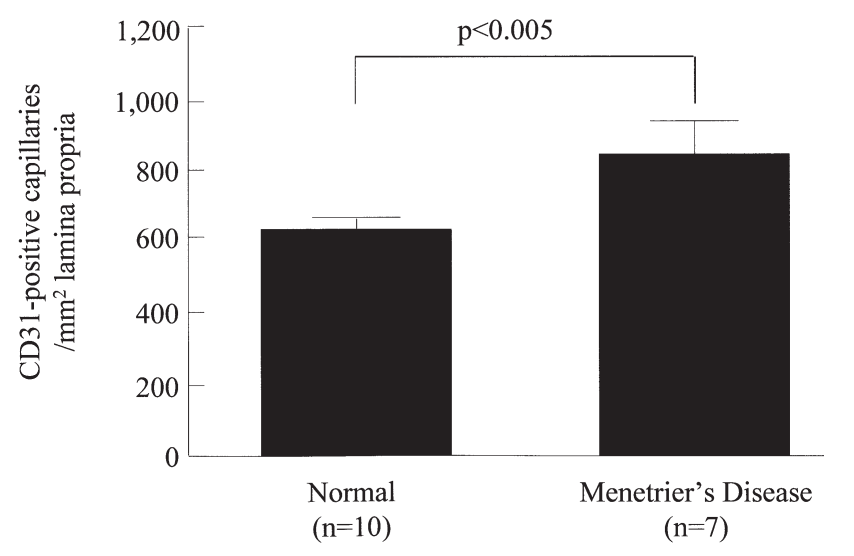

Figure 4. The number of CD31-positive blood vessels in gastric lamina propria from patients with Ménétrier's disease $(n=10)$ and controls $(n=7)$. Results are expressed as the number of CD31-positive blood vessels per unit area of the lamina propria. The mean \pm SEM is shown.

Kruskal-Wallis test. A value of $\mathrm{P}<0.05$ was considered significant.

\section{Results}

Immunohistochemistry of VEGF. The localization of VEGF in the gastric mucosa of patients with Ménétrier's disease was examined by immunohistochemical analysis. VEGF immunoreactivity was predominantly seen in LPMCs (Fig. 1). Examination of serial sections showed VEGF-positive

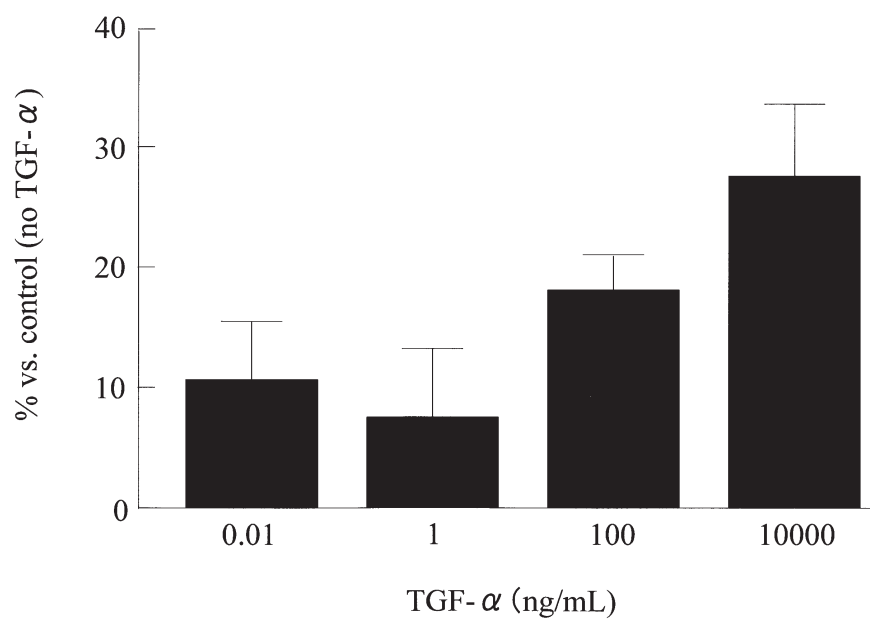

Figure 5. Effect of TGF- $\alpha$ on the production of VEGF by gastric lamina propria mononuclear cells. Lamina propria mononuclear cells $\left(2 \times 10^{6} / \mathrm{ml}\right)$ isolated from the normal gastric mucosa $(n=5)$ were recultured with different concentrations of TGF- $\alpha$ as indicated. After $24 \mathrm{~h}$, the supernatants were collected for VEGF determination by ELISA as described in the text. TGF- $\alpha$ induced the VEGF production in a dose-dependent manner $(\mathrm{P}<0.05)$.

LPMCs were localized in T-lymphocytes (Fig. 2A and D) and macrophages (Fig. 2B and E). No VEGF-positive cells were present in B-lymphocytes (Fig. 2C and F). A small number of epithelial cells also stained positive for VEGF. The number of VEGF-positive LPMCs in Ménétrier's tissue was significantly higher than those of controls $(\mathrm{P}<0.001)$ (Fig. 3A). The number of VEGF-positive epithelial cells in Ménétrier's tissue was comparable to those of controls (Fig. 3B).

Immunohistochemistry of blood vessels. CD31 was localized to various degrees in vascular endothelial cells of gastric tissue obtained from both Ménétrier's patients and controls. The number of CD31-positive blood vessels in Ménétrier's tissue was significantly higher than those of controls $(\mathrm{P}<0.05)$ (Fig. 4).

Effect of TGF-a on VEGF production. We also studied the effect of recombinant TGF- $\alpha$ on VEGF production using LPMCs. Culturing LPMCs with TGF- $\alpha$ significantly increased the production of VEGF $(\mathrm{P}<0.05)$ (Fig. 5).

\section{Discussion}

Hypoproteinemia which occurs as a result of protein-losing gastropathy is a critical problem in patients with Ménétrier's disease. Since the precise mechanism of the protein loss is still unknown, treatment has been aimed at attempting to allay symptoms although the outcome is uncertain. It has been suggested that VEGF acts selectively on vascular endo-thelial cells to induce the protein loss through vesculo-vacuolar organelles (30) and/or through expanded intracellular spaces (31). In the present study, we focused on the role of VEGF in Ménétrier's disease.

We first assessed the topographic distribution of VEGF in the gastric mucosa in patients with Ménétrier's disease. We found that VEGF expression in the gastric mucosa was largely restricted to LPMCs. Among LPMCs, VEGF is mainly produced by $\mathrm{T}$-lymphocytes and macrophages. This finding 
coincides with the results of previous studies on other disease states, where immunohistochemical staining or in situ hybridization $(32,33)$ were used. The production of VEGF in T-lymphocytes is important since it has been shown that $\mathrm{T}$ lymphocytes participate in the pathophysiology of Ménétrier's disease (16). Of particular note is that the number of VEGFpositive LPMCs in the gastric tissue of patients with Menetrier's disease is higher than that of controls. This suggests that the enhanced expression of VEGF may contribute to the gastric protein leakage associated with this disorder. Further study involving the quantitation of VEGF levels in gastric tissue by direct measurement, short-term ex-vivo culture and perfusion techniques would help support this observation. This is the first demonstration of VEGF over-expression in patients with Ménétrier's disease.

In addition to its ability to enhance vascular permeability, VEGF is also a selective promoting factor of vascular endothelial cell growth. We therefore evaluated the vascular density in tissue obtained from patients with Ménétrier's disease using CD31, which specifically recognizes vascular endothelial cells. On immunohistochemical analysis, we found a significant increase in the number of blood vessels in Ménétrier's tissue. This finding is consistent with a previous angiographic study which found hypervascular changes in the stomach of patients with Ménétrier's disease (34). Although several angiogenic factors, such as basic fibroblast growth factor (FGF), TGF- $\alpha$, TGF- $\beta$, EGF and tumor necrosis factor (TNF)- $\alpha$, have been identified, our findings strongly suggest that VEGF may contribute to angiogenesis in Ménétrier's disease.

Kondo et al reported that the activity of tissue plasminogen activator in Ménétrier's disease is enhanced, which increases gastric vascular permeability (4). It has been shown that VEGF induces tissue plasminogen activators in vitro (35). Therefore, this enhanced activity would partially be due to VEGF which is produced excessively in the gastric mucosa in patients with Ménétrier's disease.

What induces the increased expression of VEGF in Ménétrier's disease is unknown. A recent in vitro study using epidermal keratinocytes has reported that TGF- $\alpha$ is a potent inducer for VEGF (15). Since the overexpression of TGF- $\alpha$ mRNA and protein is seen in patients with Ménétrier's disease (3), we examined whether TGF- $\alpha$ induces VEGF production in the stomach. We found that LPMCs isolated from the human stomach produced VEGF in the presence of TGF- $\alpha$. At present, the concentration of TGF- $\alpha$ in the gastric mucosa of patients with Ménétrier's disease is unknown. However, our data highly suggest that TGF- $\alpha$ in high doses could stimulate the production of VEGF from the cells present in the stomach. Although other stimulatory factors must be considered, these results suggest that TGF- $\alpha$ may play an important role in VEGF synthesis in Ménétrier's disease.

In summary, LPMCs in the gastric mucosa of patients with Ménétrier's disease overexpressed VEGF. Of the LPMCs, Tlymphocytes and macrophages were the major sources of VEGF. Also, TGF- $\alpha$ induced VEGF synthesis in LPMCs. Our results indicate that the increased expression of VEGF, as a result of the overproduction of TGF- $\alpha$, may play a key role in the pathophysiology of Ménétrier's disease. Inhibiting the action of VEGF will likely be used for the treatment of hypoproteinemia in this disease.

\section{References}

1. Gastritis. In: Morson \& Dawson's Gastrointestinal Pathology Morson BC, et al (eds). 3rd edition, Blackwell Scientific Publications, London, pp94-119, 1990.

2. Takagi H, Jhappan C, Sharp R and Merlino G: Hypertrophic gastropathy resembling Menetrier's disease in transgenic mice overexpressing transforming growth factor $\alpha$ in the stomach. J Clin Invest 90: 1161-1167, 1992.

3. Dempsey PJ, Goldenring JR, Soroka CJ, et al: Possible role of transforming growth factor $\alpha$ in the pathogenesis of Menetrier's disease: Supportive evidence from humans and transgenic mice. Gastroenterology 103: 1950-1963, 1992.

4. Kondo M, Ikezaki M, Kato $\mathrm{H}$ and Masuda M: Anti-fibrinolytic therapy of giant hypertrophic gastritis (Menetrier's Disease). Scand J Gastroenterol 13: 851-856, 1978.

5. Miura S, Asakura H and Tsuchiya M: Lymphatic abnormalities in protein-losing gastropathy, especially in Menetrier's disease. Angiology 32: 345-354, 1981 .

6. Kelly DG, Miller LJ, Malagelada JR, et al. Giant hypertrophic gastropathy (Menetrier's disease): pharmacologic effects on protein leakage and mucosal ultrastructure. Gastroenterology 83: 581-589, 1982.

7. Settle SH, Washington $\mathrm{K}$, Lind $\mathrm{C}$, et al: Chronic treatment of Ménétrier's disease with Erbitux: Clinical efficacy and insight into pathophysiology. Clin Gastroenterol Hepatol 3: 654-659, 2005.

8. Senger DR, Galli SJ, Dvorak AM, et al: Tumor cells secrete a vascular permeability factor that promotes accumulation of ascites fluid. Science 219: 983-985, 1983.

9. Senger DR, Connolly DT, Water LVD, et al: Purification and $\mathrm{NH}_{2}$-terminal amino acid sequence of guinea pig tumor secreted vascular permeability factor. Cancer Res 50: 1774-1778, 1990.

10. Ferrara N and Henzel WJ: Pituitary follicular cells secrete a novel heparin-binding growth factor specific for vascular endothelial cells. Biochem Biophys Res Commun 161: 851-858, 1989.

11. Leung DW, Cachianes G, Kuang WJ, et al: Vascular endothelial growth factor is a secreted angiogenic mitogen. Science 246: 1306-1309, 1989 .

12. Keck PJ, Hauser SD, Krivi G, et al: Vascular permeability factor, an endothelial cell mitogen related to PDGF. Science 246: 1309-1312, 1989

13. Shweiki D, Itin A, Soffer D and Keshet E: Vascular endothelial growth factor induced by hypoxia may mediate hypoxiainitiated angiogenesis. Nature 359: 843-845, 1992.

14. Goldman CK, Kim J, Wong WL, et al: Epidermal growth factor stimulates vascular endothelial growth factor production by human malignant glioma cells: a model of glioblastoma multiform pathophysiology. Mol Biol Cell 4: 121-133, 1993.

15. Detmar M, Brown LF, Claffey KP, et al: Overexpression of vascular permeability factor/vascular endothelial growth factor and its receptors in proriasis. J Exp Med 180: 1141-1146, 1994.

16. Wolfsen HC, Carpenter HA and Talley NJ: Menetrier's disease: A form of hypertrophic gastopathy or gastritis? Gastroenterology 104: 1310-1319, 1993.

17. Coffey RJ, Gangrosa LM, Damstrup L and Dempsey PJ: Basic action of transforming growth factor- $\alpha$ and related peptides. Eur J Gastroenterol Hepatol 7: 923-927, 1995.

18. Weinstein WM: Hypertrophic gastropathies (giant mucosal folds). In: Gastrointestinal Disease. Pathophysiology, Diagnosis, Management. Sleisenger MH, et al (eds). 5th edition, WB Saunders, Philadelphia, pp561-563, 1993.

19. Florent C, Vidon N, Flourie B, et a:. Gastric clearance of alpha1-antitrypsin under cimetidine perfusion new test to detect protein-losing gastropathy. Dig Dis Sci 31: 12-15, 1986.

20. Takeda H, Takahashi T, Ajitsu S, et al: Protein-losing gastroenteropathy detected by technetium-99m-labeled human serum albumin. Am J Gastroenterol 86: 450-453, 1991.

21. Jaskiewicz K, Price SK, Zak J and Louwrens HD: Lymphocytic gastritis in nonulcer dyspepsia. Dig Dis Sci 136: 1079-1083, 1991.

22. Miettinen A, Karttunen TJ and Alavaikko M: Lymphocytics gastritis and Helicobacter pylori infection in gastric lymphoma. Gut 37: 471-476, 1995.

23. Parums DV, Cordell JL, Micklem K, et al: JC70: a new monoclonal antibody that detects vascular endothelium associated antigen on routinely processed tissue sections. J Clin Pathol 43: 752-757, 1990.

24. Horak ER, Leek R, Klenk N, et al: Angiogenesis, assessed by platelet/endothelial cell adhesion molecule antibodies, as indicator of node metastases and survival in breast cancer. Lancet 340: 1120-1124, 1992. 
25. Hudson N, Balsitis M, Everitt S and Hawkey CJ: Angiogenesis in gastric ulcers: impaired in patients taking non-steroidal antiinflammatory drugs. Gut 37: 191-194, 1995.

26. Fan XJ, Chua A, Shahi CN, et al: Gastric T lymphocyte responses to Helicobacter pylori in patients with $H$ pylori colonisation. Gut 35: 1379-1384, 1994.

27 Bartnik W, Remine SG, Chiba M, et al: Isolation and characterization of colonic intraepithelial and lamina proprial lymphocytes. Gastroenterology 78: 976-985, 1980.

28. Fujisaki K, Mitsuyama K, Toyonaga A, et al: Circulating vascular endothelial growth factor in patients with colorectal cancer. Am J Gastroenterol 93: 249-252, 1998.

29. Hanatani M, Tanaka Y, Kondo S, et al: Sensitive chemiluminescence enzyme immunoassay for vascular endothelial growth factor/vascular permeability factor in human serum. Biosci Biotech Biochem 59: 1958-1959, 1995.

30. Kohn S, Nagy JA, Dvorak HF and Dyorak AM: Pathway of macromolecular tracer transport across venules and small veins. Structural basis for hyperpermeability of tumor blood vessels. Lab Invest 67: 596-597, 1992.
31. Roberts WG and Palade GE: Increased microvascular permeability and endothelial fenestration induced by vascular endothelial growth factor. J Cell Sci 108: 2369-2379, 1995.

32. Berse B, Brown LF, Water LVD, et al: Vascular permeability factor (vascular endothelial growth factor) gene is expressed differentially in normal tissues, macrophages, and tumors. Mol Biol Cell 3: 211-220, 1992.

33. Brown LF, Olbricht SM, Berse B, et al: Overexpression of vascular permeability factor (VPF/VEGF) and its endothelial cell receptors in delayed hypersensitivity skin reactions. J Immunol 154: 2801-2807, 1995.

34. Uflacker R: Angiographic pattern of giant hypertrophic gastritis (Menetrier's disease). Br J Radiol 53: 909-911, 1980.

35. Pepper MS, Ferrara N, Orci L and Montesano R: Vascular endothelial growth factor (VEGF) induces plasminogen activators and plasminogen activator inhibitor-1 in microvascular endothelial cells. Biochem Biophys Res Commun 181: 902-906, 1991. 